взаємодіючими мистецтвами й народжується якісно нове мистецтво, відмінне від тих, що вступили у взаємодію.

Здатність до синтезування сприяє систематизації дійсності та уявлень про неї, знаходячи вияв у найрізноманітніших видах людської діяльності. Феномен синтезу мистецтв реалізується в єдиному художньому образі або системі образів, що об'єднані єдністю задуму, стилю, виконання, але створені за законами різних мистецтв.

\title{
Література
}

1. Ансерме Е. Беседы о музыке / Эрнэст Ансэрмэ; [пер. с франц.]. - М. : Музыка, 1985. - 104 с. 2. Каган М. Морфология искусства / Моисей Семенович Каган. - М. : Искусство, 1972. - 441 с. 3. Макаренко Г. Типологія творчого процесу диригента / Г. Макаренко // Культура і сучасність: Альманах державної академії керівних кадрів культури і мистецтв № 2. - Київ, 2004. 4. Мусін І. Язык дирижерского жеста / Илья Александрович Мусин. - М. : Музыка, 2007. - 256 с. 5. Нейгауз Г. Об искусстве фортепианной игры / Генрих Густавович Нейгауз; [метод. пособие]. - Л. : Музыка, 1958. - 202 с. 6. Хайкин Б. Беседы о дирижерском ремесле / Борис Эммануилович Хайкин. - Л. : Советский композитор, 1984. - 240 с.

УДК $378.147+159.9$

Тетяна Шепеленко

\section{КОМУНІКАТИВНИЙ СКЛАДНИК ПРОФЕСІЙНОЇ КОМПЕТЕНТНОСТІ МАЙБУТНІХ ФАХІВЦІВ ЕКОНОМІЧНОГО ПРОФІЛЮ}

Шепеленко Т. Л. Комунікативний складник професійної компетентності майбутніх фахівців економічного профілю.

У статті розкрито сутність комунікативного складника професійної компетентності майбутніх фахівців 3 економіки, здійснено порівняльний аналіз базових понять, розглянуто структурні компоненти комунікативної компетентності, визначено педагогічні умови ефективного формування комунікативної компетентності.

Ключові слова: комунікація, компетентність, професійна компетентність, комунікативна компетентність, структура комунікативної компетентності, педагогічні умови.

Шепеленко Т. Л. Коммуникативная составляющая профессиональной компетентности будущих специалистов экономического профиля.

В статье раскрыта сущность коммуникативной составляющей профессиональной компетентности будущих специалистов экономического профиля, рассмотрены ее структурные компоненты, определены педагогические условия эффективного формирования коммуникативной компетентности.

Ключевые слова: коммуникация, компетентность, профессиональная компетентность, коммуникативная компетентность, структура коммуникативной компетентности, педагогические условия.

Shepelenko T. L. Communicative component of professional competence of future economists.

The article reveals the essence of the communicative component of professional competence of future economists. The author describes its structural components, defines pedagogical conditions of effective forming communicative competence.

Key words: communication, competence, professional competence, communicative 
competence, structure of communicative competence, pedagogical conditions.

В умовах динамічної трансформації суспільно-політичного та економічного розвитку сучасного суспільства, послідовної демократизації та гуманізації взаємин усіх учасників виробничого процесу значно підвищується увага науковців до якості підготовки майбутніх фахівців економічного профілю. Пріоритет надається всебічному розвитку творчих професіоналів, здатних здійснювати ефективну комунікацію 3 іншими людьми та приймати на основі іï результатів компетентні ділові рішення. Розв'язання завдань, поставлених перед системою вищої освіти України, залежить від активного впровадження в навчально-виховний процес засад ефективного формування комунікативної компетентності студентів. Комунікативна компетентність як один із складників професіоналізму створює можливості для майбутніх фахівців економічного профілю знаходити підхід до кожного учасника трудової діяльності, переконувати його у власній точці зору, спонукати до спільної діяльності, яка, на думку О. Бодальова, «...обумовлює та програмує зміст і характер ділового спілкування людей, що беруть участь у створенні матеріального продукту...» [2, с. 70].

Науковим підгрунтям у розв'язанні проблеми ефективного формування комунікативної компетентності студентів під час вивчення педагогічних дисциплін $\epsilon$ філософські та психологічні концепції спілкування, у відповідності до яких комунікативна компетентність визначається як складник професійної компетентності (О. Бодальов, Н. Волкова, Ю. Смельянов, Ю. Жуков, М. Заброцький, Н. Завіниченко, М. Каган, В. Кан-Калик, С. Максименко, Р. Нємов, С. Руденський, С. Тармаєва та ін.).

Теоретичний аналіз свідчить, що окремі аспекти проблеми формування комунікативної компетентності особистості були предметом дослідження багатьох науковців: наукові основи сутності, особливостей і структури комунікативної компетентності (М. Заброцький, Н. Завіниченко, В. Кан-Калик, С. Максименко, Н. Усімбаєва та ін.); методологічні засади ділової комунікації (О. Бодальов, О. Леонтьєв, Б. Ломов та ін.); співвідношення професійної і комунікативної компетентності (Н. Кузьміна, А. Маркова, Л. Мітіна, А. Хуторський та ін.); визначення специфіки змісту і структури комунікативної компетентності залежно від виду діяльності [2; 5].

Однак у теорії та практиці вищої школи проблема формування комунікативної компетентності студентів вищих навчальних закладів економічного профілю у процесі вивчення психолого-педагогічних дисциплін не знайшла в науковій літературі належного відображення. Водночас практика показує, що навчальний процес здебільшого спрямовується на розвиток фахових знань і умінь, а комунікативний аспект майбутньої професійної діяльності відходить на другий план, не реалізується, що породжує суперечність між фундаментальною теоретичною освіченістю випускників і недостатнім рівнем їх підготовки до комунікативної діяльності.

Викладене вище свідчить про актуальність означеної проблеми, що потребує іiі подальшого дослідження.

Метою статmі $є$ висвітлення теоретичних аспектів комунікативної компетентності як важливого складника професійної підготовки студентів та визначення педагогічних умов їі формування.

Розкриття сутності комунікативної компетентності передбачає необхідність чіткого визначення термінів «комунікація», «компетентність», «професійна компетентність», «комунікативна компетентність».

Термін «комунікація» походить від латинського communiko, що означає робити 
загальним, зв'язувати. Означене поняття є близьким за своєю суттю 3 поняттям «спілкування», але їх не можна вважати синонімами. Слово комунікація використовується для позначення передачі інформації від людини до людини, обміну інформацією в суспільстві. Спілкування ж визначається як міжособистісна взаємодія людей під час обміну інформацією. У зв’язку з цим слід зауважити, що будь-яка комунікація є спілкуванням, однак не кожне спілкування є комунікацією.

Поняття «компетентність» у сучасних наукових працях має варіативність визначень. У «Словнику 3 педагогіки» визначено компетентність, з одного боку, як: «особисті можливості посадової особи та іiі кваліфікації (знання, досвід), які дозволяють брати участь у розробці певного кола рішень або розв'язувати питання самостійно, завдяки наявності у неї певних знань, навичок» [7, с. 133], а з іншого - як «рівень освіченості, який визначається ступенем оволодіння теоретичними засобами пізнавальної практичної діяльності» [7, с. 133]. В. Краєвський і А. Хуторський уважають, що в понятті компетентності відображений інтегрований результат поєднання певних знань і вмінь, які дозволяють людині бути обізнаною в різних аспектах діяльності та ефективно їі реалізувати [ 8].

На думку ряду науковців $[5 ; 11]$, компетентність характеризується стійкою здатністю до діяльності, яка передбачає: глибоке розуміння сутності проблем i завдань; наявність досвіду в певній галузі; вміння обирати раціональні засоби та способи дії, адекватні конкретній ситуації; почуття відповідальності за досягнуті результати; здатність вносити корективи у процес діяльності.

Ми поділяємо точку зору Ю. Татур, який запропонував визначення компетентності спеціаліста 3 вищою освітою як вияв на практиці його намагання i готовність реалізувати свій потенціал (знання, уміння, досвід, особисті якості) для успішної творчої діяльності у професійній і соціальній сфері, розуміння соціальної значущості й особистої відповідальності за результати цієї діяльності, необхідності їі постійного вдосконалення [11, с. 67].

Вище сказане дозволяє стверджувати, що про наявність компетентності необхідно судити за характером результату праці людини. Кожен працівник компетентний тїєю чи тією мірою, якою виконувана ним робота відповідає вимогам до кінцевого результату професійної діяльності. Неправомірно судити про компетентність не за результатом, а за тим, що вкладається в його досягнення, наприклад, старання людини.

Отже, ми можемо виокремити в компетентності поняття «професійна компетентність», яка у психолого-педагогічній літературі розглядається як особистісне утворення, якісна характеристика рівня володіння особистістю своєю професійною діяльністю. 3 точки зору М. Самарчук, професійна компетентність $€$ певнуою системою, що інтегрує знання, уміння, навички, професійно значущі якості особистості, яка забезпечує виконання особистих професійних зобов'язань [10].

А. Маркова розрізняє такі види професійної компетентності: спеціальна компетентність - володіння професійною діяльністю на досить високому рівні, здатність проектувати свій подальший професійний розвиток; соціальна компетентність - володіння спільною професійною діяльністю, співпрацею, а також прийомами професійного спілкування, соціальна відповідальність за результати своєї професійної праці; особистісна компетентність - володіння прийомами особистісного самовираження й саморозвитку, засобами протистояння професійним деформаціям особистості; індивідуальна компетентність - володіння прийомами самореалізації і розвитку індивідуальності в рамках професії, готовність до професійного зростання, здатність до індивідуального самозбереження, несхильність до професійного старіння. 
Названі види компетентності, на думку автора, означають зрілість людини у професійній діяльності, у професійному спілкуванні, у становленні особистості професіонала, його індивідуальності [6].

Важливим складником професійної компетентності $\epsilon$ комунікативна компетентність, яка, як підкреслюють О. Бодальов, Н. Завіниченко, В. Кан-Калик, Р. Нємов, М. Ночевник, І. Писаревський, М. Саламарчук та інші, в кожному виді діяльності має свою специфіку $[2 ; 5 ; 6 ; 10 ; 11]$.

Плідна спроба описати зміст комунікативної компетентності зроблена Р. Нємовим, який розглядає іiі як «соціально-психологічне поняття, яке означає сукупність знань, умінь та навичок спілкування з людьми» [7, с. 222].

Комунікативна компетентність, на думку Ю. Смельянова, - це моральна категорія, що регулює всю систему ставлення людини до природного й соціального світу, а також до самого себе як синтезу цих двох світів і вимагає від особистості усвідомлення власних потреб та ціннісних орієнтацій, перцептивних умінь, готовності сприймати нове в зовнішньому середовищі, своїх можливостей у розумінні норм i цінностей інших соціальних груп та культур, своїх почуттів і психічних станів у зв’язку з дією зовнішніх факторів тощо [2].

Н. Завіниченко під комунікативною компетентністю розуміє засновану на знаннях та чуттєвому досвіді спроможність індивіда орієнтуватися в ситуаціях професійного спілкування, розуміти мотиви та стратегії поведінки, фрустрації свої власні та партнерів по спілкуванню, рівень освоєння ним технології та психотехніки спілкування [3].

На думку I. Писаревського, комунікативна компетентність складається зі здатностей особистості здійснювати соціально-психологічний прогноз комунікативної ситуації майбутньої взаємодії, адаптуватися до соціально-психологічної атмосфери комунікативної діяльності та здійснювати соціально-психологічне управління комунікативною взаємодією [9].

Таке різноманіття i різноплановість трактування поняття «комунікативна компетентність» зумовлене різними науковими підходами дослідників до визначення даної дефініції.

Теоретичний аналіз дозволяє стверджувати, що комунікативна компетентність це складний феномен, який має власну структуру. До основних структурних елементів комунікативної компетентності переважна більшість дослідників відносять такі: емоційний, мотиваційний, когнітивний та поведінковий компоненти.

Спілкування з іншою людиною, оцінка іiі справ, відгук на іiі звернення суттєво впливає на вироблення в особистості стійких форм емоційних відповідей [2]. Інтерес до іншої людини та готовність вступати 3 нею в міжособистісні стосунки, високий рівень ідентифікації з виконуваними професійними й соціальними ролями, позитивна Я-концепція характеризують емоційний компонент. 3 цього приводу М. Ночевник зазначає, що «...форми міжособистісного спілкування більшою мірою залежать від почуттів, які людина відчуває до своїх рідних, товаришів по роботі, незнайомих людей. На основі цих почуттів вона виробляє стратегію поведінки і спілкування, яка може відповідати або не відповідати інтересам особистості, допомагати або заважати досягненню поставлених цілей» [8, с. 21].

Результати пізнання емоційного стану іншої людини особистістю і характер іiі власного емоційного відгуку на ці стани великою мірою залежать від мотивів, які $€$ провідними для особистості під час їі спілкування з іншими людьми, і не меншою мірою залежать від стійкості цих мотивів.

До когнітивного компоненту відносять знання про спілкування, його структуру, 
форми, види, функції, засоби спілкування (вербальні й невербальні), особливості професійного спілкування; знання про стилі спілкування, творче мислення.

Поведінковий компонент комунікативної компетентності передбачає сформованість відповідно до трьох взаємозв'язаних аспектів (комунікативний, інтерактивний, перцептивний) структури спілкування комунікативних умінь, які дають змогу успішно встановлювати контакт 3 іншою людиною та адекватно пізнавати іiї внутрішні стани й керувати ситуацією взаємодії з нею.

У результаті теоретичного осмислення проблеми 3'ясовано, що формування комунікативної компетентності у студентів детермінується продуктивною комунікативною поведінкою викладача, яка набуває ролі професійно значущої. Умовою ефективного формування комунікативної компетентності студентів $\epsilon$ створення діалогового режиму на заняттях, який передбачає обмін почуттями, власними думками чи позиціями, життєвим досвідом 3 приводу того чи іншого теоретичного питання комунікативної компетентності, що дає змогу кожному партнерові самовиразитись у спілкуванні. На формування комунікативної компетентності студентів ефективний вплив здійснює навчальний тренінг як форма спеціально організованого навчання для самовдосконалення особистості, в ході якого розв'язуються такі завдання: оволодіння соціально-психологічними знаннями; розвиток здатності пізнання себе та інших людей; підвищення уявлень про власну значущість, цінності, формування позитивної Я-концепції.

Отже, теоретичний аналіз дозволяє стверджувати, що комунікативна компетентність характеризується наявністю знань, чуттєвого та практичного досвіду індивіда, які допомагають йому орієнтуватися у ситуаціях професійного спілкування, розуміти стратегії та мотиви поведінки свого співрозмовника та свої власні.

\section{Література}

1. Бодалев А. А. Личность и общение: избранные труды / А. А. Бодалев. - [изд. 2-е, перераб.]. - М. : Международная педагогическая академия, 1995.- 328 с. 2. Емельянов Ю. Н. Обучение паритетному диалогу: [учебное пособие] / Ю. Н. Емельянов. - Л. : Изд-во ЛГУ, 191. - 106 с. З. Завіниченко Н. Б. Особливості розвитку комунікативної компетентності майбутнього практичного психолога системи освіти: автореф. дис. на здобуття наук. ступеня канд. пед. наук: спец. 19.00.07 «Педагогічна та вікова психологія»/ Н. Б. Завіниченко. - К., 2003. - 20 с. 4. Коджаспирова Г. М. Словарь по педагогике / Г. М. Коджаспирова, А. Ю. Коджаспиров. - М. : ИКЦ «МарТ», 2005. - 448 с. 5. Краевский В. В. Основы обучения. Дидактика и методика / В. В. Краевский, А. В. Хуторской. - М. :Академия, 2007. - 352 с. 6. Маркова А. К. Психология труда учителя / А. К. Маркова. - М. : Просвещение, 1993. - 192 с. 7. Немов Р. С. Психология. Словарь-справочник / Р. С. Немов. - М. : Изд-во Владос-Пресс, 2003. - 304 с. 8. Ночевник М. Н. Человеческое общение / М. Н. Ночевник. - М.: Политиздат, 1988. - 128 с. 9. Писаревський I. М. Професійно-комунікативна компетентність (в туризмі): [підручник] / I. М. Писаревський, С.А.Александрова. - Харків: ХНАМГ, 2010. 230 с. 10. Самарук Н. П. Формування професійної компетентності майбутніх економістів / Н. П. Самарук // Електронне наукове фахове видання. - 2011. - № 2. С. 98. 11. Татур Ю. Г. Компетентностный поход в описании результатов и проэктировании стандартов высшего профессионального образования / Ю. Г. Татур. М. : Исследовательский центр проблем качества подготовки специалистов, 2004.C. 67. 